\title{
Social Construction Fandom as Cultural Industry Marketing of JKT 48 Fan Group
}

\author{
Ahmad Mulyana, Rizki Briandana, Dwi Anggraini Puspa Ningrum \\ Universitas Mercu Buana, Jl. Meruya Selatan, Kec. Kembangan, Jakarta Barat, Daerah Khusus Ibukota Jakarta 11650
}

\begin{tabular}{|c|c|}
\hline ARTICLE INFO & A B S T R A C T \\
\hline \multirow[t]{3}{*}{$\begin{array}{l}\text { Keywords: } \\
\text { marketing communication, } \\
\text { Fandom, } \\
\text { culture industry, } \\
\text { JKT48 }\end{array}$} & $\begin{array}{l}\text { The aim of this research is to analyzed the social construction of } \\
\text { marketing of the JKT48 fandom group in the context of the cultural } \\
\text { industry context. The culture industry can be interpreted as cultural } \\
\text { production and consumption or contribution to cultural production. } \\
\text { This reality is one of the popular culture products which is quite } \\
\text { popular with a group of JKT } 48 \text { fans. This study uses a case study } \\
\text { method with interview and observation as data collection technique. } \\
\text { The results show that the social construction of fandom is formed on } \\
\text { the same interest in a cultural form. The presence of JKT48 gives a new } \\
\text { color in forming a subculture about the concept of become a fan as a } \\
\text { consumer of popular culture. This relates to the marketing of a culture } \\
\text { as a form of cultural industry as a contribution in cultural production. }\end{array}$ \\
\hline & SARI PATI \\
\hline & $\begin{array}{l}\text { Industri budaya secara khusus dapat diartikan menjadi produksi dan } \\
\text { konsumsi barang dan jasa budaya atau kontribusi dalam produksi } \\
\text { budaya. Sifat individu untuk menyukai dan menggemari musik, buku, } \\
\text { film, seni rupa, olahraga dapat menjadi sasaran dari pengembangan } \\
\text { industri budaya, penyuka, penggemar musik bahkan terkonstruksi } \\
\text { menjadi konsumen. Tidak sedikit orang yang memiliki ketertarikan } \\
\text { secara mendalam terhadap suatu produk budaya misalnya seperti } \\
\text { halnya musik, kemudian mengidentifikasikan dirinya sebagai seorang } \\
\text { fans. Realitas ini lah JKT48 merupakan salah salah satu produk } \\
\text { budaya populer yang cukup besar digemari oleh sekelompok orang. } \\
\text { Fans JKT48 yang tersebar di Indonesia tentunya bukan jumlah yang } \\
\text { sedikit, sehingga terbentuklah fandom (fans kingdom) JKT48. Bukan } \\
\text { hanya mengkonsumsi musik JKT48 fandom JKT48 lebih dari itu fans } \\
\text { terkonstruksi dalam lingkup pemasaran industri budaya dengan } \\
\text { memproduksi konten tentang idol group favorit mereka. }\end{array}$ \\
\hline
\end{tabular}




\section{INTRODUCTION}

The development of the culture industry has significantly increased from time to time and can be interpreted specifically as a contribution in cultural production (Amiri, Kavousy, \& Hosseinzadegan, 2010). The countries most dominant in marketing the culture industry are Korea, Japan, America and the United Kingdom, reaching 53\% (Group of Writers, 2001). Some countries with a history of cultural industry production offer high quality standards throughout the production process in the package of a global media and entertainment company presence. These factors will strengthen the existing export markets and contribute to the development of new niches in the world market and the main reason for this condition is the utilization of the power of software by a series of countries to influence consumers of other countries (Kotler, Kartajaya, \& Setiawan, 2016). As the development of cultural exports have economic and cultural value and design models for cultural exports that are appropriate to the cultural system of the destination country by conditioning the fulfillment of the needs and desires of cultural industry consumers that are more appropriate so that the consumption of cultural products (Liliweri, 2003). This research focus is to identify the most influential marketing factors in the development of exports of cultural goods.

Cultural industry products in the Indonesian consumer format are constructed in the context of the entertainment world. One of them is the presence of JKT48 in 2011 in Indonesia. JKT 48 was one of the first sister groups outside Japan that started with a leading idol group, AKB48 (Akihabara, Tokyo). Yasushi Akimoto is the initiator and producer of AKB48 who has successfully expanded its wings by forming other sister groups in several countries such as SKE48 (Sakae, Nagoya), NMB48 (Namba, Osaka), HKT48 (Hakata, Fukuoka), NGT48, JKT48 and BNK48 (Bangkok, Thailand ).

JKT48 is a form of transnationalization carried out by AKB48 in Indonesia. The emergence of JKT48 in the realm of the country's entertainment industry is the globalization of Japanese culture in Indonesia. Homogenisation of Japanese culture from concept, member appearance, costumes, song lyrics to product sales. Hall (1992) explains related to popular culture, where culture in everyday life is given to everyone more than just entertaining. As with performances, expressions and symbols that spread to human culture.

Reporting from Tirto Article (2016), in general, idol groups are not just musical groups. Its members are educated to become multitalented artists. Unlike the girl band or boy band who are trained to appear limited to the stage. In Japan, idols no longer refer to "idols". Idol has been interpreted as someone who not only sings but also works as an actor, model, host and commercial spokesperson. According to the official website of JKT48, the objective of establishing JKT48 is to become a national idol. In the group not only got dancing and singing education, but also a variety of knowledge to become an idol. JKT48 Academy will gather girls who have dreams from all over Indonesia to be able to learn to realize their dreams.

JKT48 fans are mostly male, generally have someone idolized in the idol group. Various terms appear such as Oshimen (the most liked member), Oshihen (move to other members who are liked) and Oshiaad (add to the list of members who are liked) (Permana, 2014). JKT48 fans known as Wota are someone who is obsessed with idols. Wota is not always about JKT48, but rather a fan of the idol group as a whole. Eric Prideaux in the article "Wota Lota Love" in the Japan Times, explained that Wota is a composition of the word otaku, which represents someone who has an obsession with something especially in anime and manga. Otaku are mentioned as people who are willing to wake up early to secure a queue of photo sessions with artists or idols (Permana, 2014). They are children who spend their childhood in the best schools but end up with losers with pleasing faces. These people are referred to as maniacs or fanatics, but 
nothing is really appropriate. So they agreed to be called otaku, that's what Nakamori Akio wrote in "This City is Full of Otaku" which aired on Manga Burikko (Permana, 2014).

This study uses a case study method with the aim of analyzed the social construction of marketing of the JKT48 fandom group in the context of the cultural industry context. In this study the authors not only observed, but also joined in the JKT48 fandom cultural life. In addition to observing and entering into the scope of JKT48 fandom, researchers also conducted in-depth interviews with JKT48 fans to explain how the producer-consumerism relationship was constructed in JKT48 fandom.

\section{CONCEPTUAL FRAMEWORK OF THE STUDY}

\section{Marketing Strategies in the Culture Industry}

Many marketing researchers broadly opine marketing strategy to be a concept built on a strong platform of segmentation, targeting and positioning (Manser Payne, Peltier, \& Barger, 2017). The marketing strategy demands must be able to decide about the specific target customers. In addition, a marketing mix can be developed to target the market by positioning it in the most specific way (Ballantyne, 2003). Consumer insight is needed so that they can better understand the needs and desires of consumers (Schultz, Tannenbaum, \& Lauterborn, 1994). For marketing cultural products, producers must really be able to identify deeply and in detail what each individual's tastes are related to the world of entertainment. Cultural products must be able to build consumer awareness about the diversity of cultural expressions through associative strategies with certain groups. For example, by integrating strategies with information technology approaches to distribute alternative culture or entertainment that allows dissemination to the niche market, forms of non-mainstream expression, or forms created by communities or minority groups. Some cultural policies focus on interdependent relationships between social and economic dimensions of culture. Such a holistic policy would be ideal for promoting sustainability in the development of the cultural industry (Wahab, 2012). Important transformation is implemented through marketing activities through the power of new media. Nowadays, social construction is conditioned to develop communication initiatives to connect individuals and communities in a personal way to celebrities in art and entertainment. With multilateral agency relations to raise awareness or funding for various reasons; mainstream artists are now entering the alternative global consumption circuit; and local institutions in collaboration with international organizations to produce content or programs and large-scale cultural products (Nikoomaram, Soltani, \& Kavousy, 2010).

Cultural industry marketing strategies such as these produce complex effects which condition the way local content and actors can impact the environment around them. Often, these actions risk losing the power to shape the local cultural agenda. The risk is quite clear in cases where the State has little or no role in funding public media, building public strategies, or lacking the capacity to regulate or negotiate among various interests.

\section{Fandom in JKT48}

Fandom according to Jenkins (2007) are two words that are combined, namely fan (fans) and kingdom. In fandom there are special forums that allow fans to carry out massive experiences through fandom on social media. Besides fandom is a term given by the community to enjoy a particular subject in order to meet and communicate with other people who have the same interests (Gray, 1999). Fans use the internet as a medium to satisfy desires related to idols (Jenkins, 2007).

Fiske (2012) states what is assumed by fans tends to deviate and is excessive activity. Fans are groups who consume and enjoy popular culture texts more than most people in general. Developing stereotypes tell more about the influence of dominant schools of social thought than about groups of fans, so that fans are never positively and positively positioned. 
Fan involvement can be seen through their activities in processing media content. Fans are categorized as active audiences, forming a community consisting of each other to consume and produce media content over a long period of time. This triggers them to not only produce media content they like, but also distribute to fellow fans in a wider range. Fans who are getting closer to this media content can cause fanaticism. Fanaticism is a behavior that reflects the image of fans. Excessive fan obsession is often shown by deviant behavior. They involve themselves deeply and do all activities to fulfill their fans' desires.

The term "fan" is an abbreviation of "fanatic," which has traditionally been associated with religious zealotry. Given the negative association with the label of fanatic as someone who is unstable, violent, or abnormal, the usage of the less condemning term "fan" has become commonplace, particularly given the widespread social acceptance of being a sport fan (Plante, Roberts, Reysen, \& Gerbasi, 2014).

Fans in JKT48's fandom are oriented toward getting closer to idol members by wearing merchandise depicting their idols and dancing typical of "wotagei" fans, shouting enthusiasm, buying albums released by idols, and coming to events organized by idols. Wota also has favorite merchandise collected as a sign that fans should support their idols by buying items sold by JKT48. Most items collected are items sold at concerts or bought online through the JKT48 official website. There are no official levels or strata to join fandom, in fact in JKT48 fans, strata are formed by fandom itself. The level is assessed based on the frequency of a fan visiting the JKT48 theater located in the FX Sudirman mall, Jakarta. The intensity of meeting with members (JKT48 members) is also a factor of JKT48 fandom strata. Not only that, there are other factors that are no less important as part of JKT48's fandom, namely the level of wealth in which how many fans collect merchandise and swag is also an important count of a fan's loyalty. This is similar to what was mentioned by Fiske (2012) a fandom can be categorized by two main activities, namely discrimination and productivity.

"fan discrimination has affinities to both the socially relevant discrimination of popular culture and the aesthetic discrimination of the dominant (Fiske, 2012)".

Table 1. Tabel JKT48 fandom classification

\begin{tabular}{ll}
\hline \multicolumn{1}{c}{ FANDOM } & \multicolumn{1}{c}{ DESCRIPTION } \\
\hline JKT48 Member Fandom & $\begin{array}{l}\text { Each member or member of JKT48 has their own fans who are } \\
\text { members of a fandom. Example: Cindy Reaction's Fandom which } \\
\text { is a fandom from Cindy JKT48. }\end{array}$ \\
\hline Regional Fandom & $\begin{array}{l}\text { JKT48 fandoms are categorized by city area. Example: JKT48 } \\
\text { Jakarta fandom, JKT48 Bandung fandom, JKT48 Surabaya fandom, } \\
\text { etc. In an area like Jakarta, JKT48 fandom can be subdivided into } \\
\text { JKT48 fandom in South Jakarta, West Jakarta, etc. }\end{array}$ \\
\hline Team Fandom & JKT48 fans are divided into three categories, namely J fans, K fans, \\
& and T fans. Each fan from that category has their own fandom. \\
\hline Fandom Per Generation & $\begin{array}{l}\text { Fandom per generation is a collection of fans who support JKT48 } \\
\text { members based on the generation of each member in JKT48. } \\
\text { Example: Melody and Haruka are the first generation of JKT48. } \\
\text { There is a fandom from JKT48 generation tips }\end{array}$ \\
\hline
\end{tabular}

Source: JKT48 Social Media 


\section{Fandom Culture}

JKT48 fans are known to have a high degree of independence and creativity so they can form fandom to stay alive since its appearance in 2011 until now. As stated by Fiske that popular culture is produced by people from the cultural industry itself. This has been done a lot by Bacon-Smith (1988) who show the productivity of fans of a science fiction TV, where they produce videos for their own music by editing some favorite parts into a soundtrack.

Fan productivity is not limited to the production of new texts: it is also participates In the construction of the original text and thus the commercial narrative or performance into popular culture. Fans are very participatory . . . Fans produce and circulate among themselves texts which are often crafted with production values as high as any in the official culture (Silverstone, 1994).

Discussing about culture, along with the times, cultural change has an increasingly complex definition. Adorno and Horkheimer explained that culture is now fully interconnected with political economy and cultural production by capitalists. It is better to discuss popular culture if you first examine the meaning of 'culture' and 'pop'. Culture can be used to refer to a general process of intellectual, spiritual and aesthetic development (Rashid, Rahman, \& Butt, 2017). In addition, 'culture' is also defined as a particular view of life of a particular community, period, or group (Plante et al., 2014). If we discuss the development of Western European culture by using this definition, it indicates that we are not merely thinking about intellectual and aesthetic factors, but also the development of literature, entertainment, sports, music and religious ceremonies. Williams also said that culture can also refer to intellectual works and practices, especially artistic activities. The practice is assumed to have the main function to show, sign (to signify), produce, or sometimes become events that create certain meanings. (Kim, 2008). Culture was created to meet the interests of certain parties to achieve ideology or the business field. Cultural elements found in humans in the form of creativity, taste and intention. These three elements cannot be separated to achieve the essence of human perfection.

Culture is the product of a whole series of social processes carried out by humans in society with all its activities. Thus, culture is the tangible result of a social process carried out by humans and their communities (Bungin, 2008). In cultural theory, there are a number of understandings that revolve around themes such as; first, culture tends to be opposed to material, technological, and structured. Second, culture is seen as an ideal, spiritual and non-material domain. Third, cultural autonomy gets more emphasis. Fourth, a number of attempts were made to remain in the value-neutral zone (meaning not one-sided) such as equating culture as art (Smith, 1991).

According to Smith (1991), the notion of culture today is opposed to material, technological, and social structures in a more abstract sense. Culture is seen as ideal, spiritual, non material, and autonomous to economic power, the distribution of power or the needs of social structures. The concept of culture has also shifted from what was originally a noun to a verb where today's culture is understood as a productive activity, not a product of its production. This shows that the concept of culture is no longer a static understanding but has changed into a dynamic understanding.

Cultural studies cannot be separated from the history of its emergence in the United States that created music programs such as MTV, fast food such as McDonald's, Walt Disney animations, and so on. Other countries such as Japan, Hong Kong, Taiwan and Korea also gave birth to and developed pop culture such as anime and animated cartoons. Besides America, Japan and Korea are big countries that accept the spread of pop culture, with the inclusion of manga films and animations such as Doraemon as well as Korean drama, boy band and girl band. This shows that pop culture can 
be accepted by all groups and develops across continents, pop culture becomes part of mass culture that is created in accordance with market tastes (market-driven).

Williams gives four meanings in the term 'popular'. First, many people like it. Second, the kind of lowly work. Third, work done to please people. Fourth, culture that is made for himself (Hauser, 2012). Pop culture can be defined as a culture that is fun and liked by many people. Pop culture can also be interpreted as a sub-standard culture, namely the residual category (residual) to accommodate high cultural practices. In addition, pop culture is a mass culture that is produced by the masses for mass consumption. This culture is consumed without considering whether the culture is acceptable in society or not, pop culture is considered a world of collective dreams. Other meanings about pop culture which are postmodernism thoughts, thus there is no longer a difference between high culture and pop culture.

Cultural studies assume that culture is political in a very specific sense, namely as a realm of conflict and struggle. Cultural studies are seen as important sites for the production and reproduction of social relations in everyday life. An excellent elaboration on how to see this culture might come from Stuart Hall, he illustrates;

Pop culture is a place where hegemony emerges and takes place. It is not the realm where socialism, a fully formed socialist culture, can really be demonstrated. However, it is one of the places where socialism may be given legality. That is why pop culture is important (Hall \& Du Gay, 1996).

Culture is more politically defined than aesthetically. The object of study in cultural studies is not culture that is defined in the narrow sense, that is, as a high culture object and also not culture that is defined in the same narrow sense, namely as a process of aesthetic, intellectual, and spiritual development but culture which is understood as text and living practice daily.

\section{METHODOLOGY}

The qualitative approach used in this study is related to the need to explore and explain phenomena and to develop theories. The methodology used is a case study. According to Yin (2006) a case study is an empirical study that looks at contemporary phenomena in the context of life.

In this perspective, the case study method can be seen as a longitudinal study. This is because object observation covers a long and continuous period, but is formed in a cross-sectional construction. That is, it can shorten the observation time into several stages of development by drawing the same conclusions as a longitudinal study (Bungin, 2001). In addition, the use of case studies in this research is due to the focus to describe, explain in depth and explore a case (Barker \& Mathijs, 2012).

\section{Primary Data}

The primary data in this study was conducted by interviewing informants and interactions with JKT 48 fans. A total of 8 JKT 48 fans were informants in this study. The collection technique used is in two ways, namely: in-depth interviews and observation. The choice of this interview form is because the informants who were considered important in the research, the informants not only gave information about it, but also could provide advice about other sources of evidence that support.

The second is direct observation data collection techniques. Specifically the implementation of direct observation and participants in this study were carried out by: Direct observation, namely by observing the interaction of JKT 48 fans, observations here were made by accessing their sites and social media by utilizing the "tracking" feature for each informant.

RESULTS AND DISCUSSION

Social Construction Fandom 
An interest in JKT48 that starts from other people's information has a big influence on the daily activities of individuals. The music that is usually listened to changes with JKT48 songs, in terms of time a person who has become a fan will voluntarily buy tickets for JKT48 regular performances at the FX Sudirman theater building and various other idol group performances. In terms of media consumption behavior, someone who is not yet a fan, on average uses conventional media such as print media (magazines and tabloids), television and radio. When individuals are already fans, their ways of consuming media content also change to become more active by using various digital media platforms such as social media, podcasts and YouTube. Based on data it can be seen that there has been a change in the way a person consumes pop culture product content from the conventional method to a comprehensive approach to all media platforms. Before someone becomes a fan who idolizes a person or group, then the individual is somewhat passive in consuming media. Passive here means not exposed to information on his own search, but from other people. This was felt by the informant, who got a lot of information about the JKT48 idol group from his colleagues who showed many photos and videos of JKT48's performance. What the informant saw about JKT48 began to feel good and made him a new member as a JKT48 fan.

Being a fan especially for those who are members of fandom, their media consumption behavior for information related to their idols in this case JKT48 will be binding. Fans continue to find out about the development of information and the lives of their idols. Media consumption behavior as fans, especially JKT48, is divided into two, namely, how media consumption behavior as fans meet their information needs about idols and how fans consume media behavior as self-existence and efforts to gain recognition as fan members in fandom.

The results showed the culture of JKT48 fans is somewhat unique. In an effort to show his existence as a fan of JKT48, the informant made merchandise in the form of bags, clothes and jackets with designs made by himself so that it could be mass produced by other JKT48 fandoms. The income obtained from the sale of merchandise will be used to support his idol members so that they can get the highest rank and continue to exist as JKT48 members. It is inevitable that consumption practices cannot be separated from the lives of fans for the sake of meeting the needs and recognition as part of a fan group. Storey \& Rahmawati (2008) stated that fans were understood as passive victims and mass media catalogers who gave rise to negative stereotypes. The most common negative stereotype shown is the hysterical crowd (generally women) and obsessed individuals (generally men) born of certain readings are seen as psychological symptoms of social dysfunction.

A fan will follow the fandom style where they take shelter. Support is shown not only by buying JKT48 song CDs, watching concerts, becoming followers of his social media accounts but also having to be a producer to be able to produce other cultural products in order to make his idol name more popular. It is a symbolic creativity that is done by fans of pop culture.

In this context, there is a link between results of the research with pop culture, where the development of media and technology also produces new cultures in Indonesia. The ease of obtaining and distributing information and media can spread a new culture. The rapid development of media technology can also affect changes in people's behavior. Besides mass media is also an important factor in the spread of popular culture in an area or country. Literacy states that popular culture is culture created by the mass media itself, as mentioned by McQuail (2010);

Mass media is an institution that connects all elements of society with one another by starting the mass media products produced. Specifically the media institutions are (1) as a channel for the production and distribution of symbolic 
content; (2) as a public institution that works according to existing rules; (3) participation as either the sender or recipient is voluntary; (4) using professional and bureaucratic standards; (5) media as a combination of freedom and power.

The media has become a new 'religion' and 'God' in pop culture. Community behavior is no longer determined by existing religions, but has unwittingly been 'governed' by the media. The media has its own set of values and ideologies which incidentally are the extension of the product of capitalism. At the same time the media has introduced a new generation, namely cultural homogenization. That's the pop generation that worships consumerism, hedonism and an instant lifestyle.

The results showed that JKT48 fans were consuming content and products created by Japanese idol sister groups through the mass media. The mass media is also the facilitator of the formation of the JKT48 fandom which consists of various levels of society both young and old, men and women, as well as various tribes and religions. The media creates space for JKT48 fans to be able to continuously enjoy the products created by producers, without realizing fans who are members of JKT48 fandom have become a consumer society.

Digital media has been assumed by various parties as a device that requires high technology, people who work in the world of education tend to have a penchant for always making an innovation in the learning environment. This technology will form a new culture, where digital media is full of creative potential but at the same time also has the potential to abuse and even abuse both verbal and non verbal (Wahab, 2012). Within the scope of media literacy, digital media is used for media and the public to be able to access channels, sites and social media that channel various information and interests needed. Whereas in the realm of world politics, digital media is a 'tool' for accessing social media to be used as a medium for image formation and self-image.
With the development of digital media so massive and conventional media cannot continuously provide space for fans to feel closer to an idol, JKT48, the management also utilizes YouTube digital media so that fans can continue to access information about their idols and at the same time become a virtual space for members and other fandoms to exchange information. This is demonstrated through JKT 48 account which has subcriber accounts of up to 619 thousand.

\section{MANAGERIAL IMPLICATIONS}

In the context of this study, the social construction of JKT48 fandom marketing groups in the cultural industry found that JKT48 fans are new phenomenon that can be seen from habits of Indonesian. With their unusual actions such as chanting, wotagei, collecting merch until coming to handshake event, it's seen as skewed. But in the other side, JKT48 fans know for sure the reason they remain as fans. Fans certainly dunno see themselves as deviating or strange in everydays, they assume that their fandom behavior is a manifestation of their liking towards JKT48 and doesn't interfere with others. Regarding practicing chant, wotagei and other collective behaviors are considered normal behavior, fans naturally understand and buy these fandom items. Using the concept of "idol you can meet" everydays", JKT48 becomes an opiated for youth generation in Indonesia. JKT48 market is children aged 17-25yo, but not a few adults aged 30yo and over became part of JKT48 fandom.

Meanwhile, it was shown that JKT 48 fans were classified as consumers in consuming JKT48 cultural products. This is evidenced by the high number of merchandise sales every week at the concert activities.

\section{CONCLUSION}

The social construction of fandom is formed on the same interest in a cultural form. The presence of JKT48 in the study of pop music culture, in addition to providing a new color in forming a subculture about the concept of how to become 
a fan as well as a consumer of popular culture. This relates to the marketing of a culture as a form of cultural industry which is defined as the production and consumption of cultural goods and services or contributions to cultural production. Fandom activities have become a new culture of urban society in enjoying entertainment content that was previously conventionally enjoyed into entertainment content that is enjoyed in the context of digital culture. In addition, JKT48 fandom has an active role as a producer that produces content about their idols and disseminates them in various media so that they can be enjoyed by other fans.

Researchers concluded that a person's consumption behavior turns into more active when he is already a fan and becomes part of fandom. The change in behavior in how to consume more active media becomes a new culture as a way to enjoy the culture industry. Digital media encourages great influence to show one's existence as a fan.

REFEREN CES

Amiri, S. R. S., Kavousy, E., \& Hosseinzadegan, Z. (2010). The Role of Export of Cultural Goods in Cultural Development of Iran. European Journal of Social Science, 14(4).

Ballantyne, D. (2003). A relationship-mediated theory of internal marketing. European Journal of Marketing, 37(9), 1242-1260.

Bungin, B. (2001). Metodologi penelitian kualitatif: Aktualisasi metodologis ke arah ragam varian kontemporer. Jakarta: Grafindo.

Bungin, B. (2008). Konstruksi Sosial Media Massa: Kekuatan Pengaruh Media Massa, Iklan Televisi dan Keputusan Konsumen serta Kritik Terhadap Peter L. Berger \& Thomas Luckmann.

Fiske, J. (2012). Pengantar ilmu komunikasi. Jakarta: Rajawali Press.

Gray, A. (1999). Audience and Reception Research in Retrospect: The Trouble with Audiences. Rethinking the Media Audience: The New Agenda, 22-37.

Hall, S., \& Du Gay, P. (1996). Questions of cultural identity. London: Sage.

Hauser, R. (2012). Cultural Identity in a Globalised World? A theoretical approach towards the concept of cultural identity., $1-17$.

Jenkins, H. (2007). The future of fandom. Fandom: Identities and Communities in a Mediated World, 357-364.

Kim, Y. (2008). Media, consumption, and everyday life in asia. (Y. Kim, Ed.), Intersections of Media and Communications: Concepts and Critical Frameworks. New York: Routledge.

Kotler, P., Kartajaya, H., \& Setiawan, I. (2016). Marketing 4.0: Moving from traditional to digital. John Wiley \& Sons.

Liliweri, A. (2003). Makna budaya dalam komunikasi antarbudaya. Yogyakarta: PT LKiS Pelangi Aksara.

Manser Payne, E., Peltier, J. W., \& Barger, V. A. (2017). Omni-channel marketing, integrated marketing communications and consumer engagement: A research agenda. Journal of Research in Interactive Marketing, 11(2), 185-197.

McQuail, D. (2010). Mass Communication Theory. London and New York: Sage publications.

Mulyana, A. (2017). Sekaten tradition: The ritual ceremony in Yogyakarta as acculturation reality of Javanese culture in Indonesia. International Journal of Humanities and Social Science Studies, IV(2), 50-61.

Nikoomaram, H., Soltani, M., \& Kavousy, E. (2010). The Cession of Cultural Activities to the Private Sector in Iran. European Journal of Social Sciences, 12(4).

Permana, A. (2014). Studi Fandom JKT48 Sebagai Pop Culture. Jurnal Common Line Departemen Komunikasi, 3, 442-453. 
Plante, C. N., Roberts, S. E., Reysen, S., \& Gerbasi, K. C. (2014). "one of us": Engagement with fandoms and global citizenship identification. Psychology of Popular Media Culture, 3(1), 49.

Rashid, K., Rahman, B. H., \& Butt, A. R. (2017). Journal of Media Studies Media Consumption and National Identity Formation of Adolescents in Pakistan. Journal of Media Studies, 32(1), 1-31.

Richards, J. I., \& Caywood, C. L. (2014). Symbolic speech in political advertising: encroaching legal barriers. Television and Political Advertising, 2, 231-256.

Schultz, D. E., Tannenbaum, S. I., \& Lauterborn, R. F. (1994). The new marketing paradigm: Integrated marketing communications. McGraw Hill Professional.

Shaw, A. (2016). Representation in Video Game Play: An audience reception study Identity, Identification , and Media Representation in Video Game Play : An audience reception study.

Silverstone, R. (1994). Television and Everyday Life. London and New York: Routledge.

Smith, A. D. (1991). National identity. Las Vegas: University of Nevada Press.

Storey, J., \& Rahmawati, L. (2008). Cultural studies dan kajian budaya pop: pengantar komprehensif teori dan metode. Jalasutra.

Wahab, J. A. (2012). Global Media Product and Construction of "Japanese Identity ": a Case Study of Anime on Malaysian Television. Jurnal Komunikasi, 28(2), 1-19. Retrieved from http://www.ukm.my/jkom/journal/pdf_files/2012/V28_2_1-19. pdf

Yin, R. K. (2006). Case study methods. Handbook of complementary methods in education research (Vol. 3). London: Routledge. 